\title{
Educação e infância em Espinosa
}

Fernando Bonadia de Oliveira

Doutorando em Filosofia pela USP

Homero Santiago

Professor do Departamento de Filosofia da USP

[ $]\left[\begin{array}{l}\text { á dez anos o estudo da filosofia de Espinosa era raro } \\ \text { em faculdades de educação. Além de textos curtos e } \\ \text { antigos, havia apenas umas poucas tentativas de }\end{array}\right.$ avizinhar o pensamento espinosano do campo educacional. Recentemente, porém, começaram a ser feitas aproximações muito mais aprofundadas, seja em monografias de conclusão de curso, dissertações de mestrado, teses de doutorado ou em artigos científicos. Diante deste quadro, a produção de um dossiê exclusivamente destinado a explorar as relações entre espinosismo, educação e infância representa um passo importante no sentido da ampliação do conhecimento de Espinosa por educadores e pedagogos tanto quanto da consideração de questões pedagógicas por filósofos dedicados ao espinosismo. Eis o espírito que guiou a composição deste dossiê.

Espinosa nasceu em Amsterdã em 1632, numa família de judeus portugueses que, tendo sido obrigada à conversão para o cristianismo, buscou refúgio nos Países Baixos. O jovem Baruch recebeu uma educação judaica rigorosa, que lhe outorgou amplo conhecimento da língua hebraica e extrema habilidade na leitura dos textos sagrados. 
Após o falecimento do pai, ansioso por alargar seus horizontes intelectuais, o jovem buscou aprofundar seu conhecimento das tradições medieval e renascentista, além evidentemente do pensamento moderno, no interior do qual se dedicou especialmente à filosofia de Descartes. Em seu convívio com o ex-jesuíta Van den Enden, estudou o platonismo, o aristotelismo, aprofundou seu domínio do latim e travou conhecimento com a revolução científica que seu século produzia.

Assim que seus pensamentos começaram a ser esboçados e comunicados entre companheiros, Espinosa passa a ser considerado por muitos inimigo da religião, o que lhe trouxe, rapidamente, problemas com a comunidade judaica a que pertencia. Após ter sido admoestado várias vezes para que se retratasse dos seus pensamentos e de suas conclusões, foi, finalmente, excomungado.

A excomunhão levou o filósofo a se aproximar cada vez mais intensamente de um círculo de amigos de Amsterdã que na mesma época se dedicava a estudar, entre outros assuntos, o cartesianismo, a grande novidade filosófica de então. A primeira publicação de Espinosa, os Princípios da filosofia cartesiana, lançada com um apêndice intitulado Pensamentos metafísicos ocorreu em 1663; esta obra apresenta os fundamentos do pensamento cartesiano na forma de demonstrações geométricas, com o escopo de contrapô-las às leituras dogmáticas das ideias de Descartes que já eram feitas por alguns.

Antes dos Princípios da filosofia cartesiana, produzidos a partir das aulas que ministrou sobre o cartesianismo a um aluno chamado 
Caseário, Espinosa elaborara um Breve tratado sobre Deus, o homem e seu bem-estar, destinado a discípulos e amigos, e iniciou a composição do Tratado da emenda do intelecto, abandonando-o incompleto. Este último escrito explicita, em seu décimo quinto parágrafo, que a "educação das crianças" tem um lugar fundamental no conjunto do pensamento espinosano.

A Ética demonstrada segundo a ordem geométrica, tida como a obra maior do espinosismo, foi composta em meio a um importante intercâmbio epistolar através do qual o filósofo e seus discípulos discutiam suas proposições e demonstrações. A partir deste diálogo, Espinosa pôde modificar a obra, aperfeiçoando-a em vários pontos. A escolha da ordem geométrica para a elaboração da Ética teria sido motivada, segundo algumas interpretações pedagógicas, por uma preocupação didática do autor, interessado em expor sua filosofia segundo um método de ensino próprio.

Os tratados Teológico-político e Político (o primeiro publicado anonimamente em 1670, o segundo interrompido pela morte do autor em 1677) apresentam, em seus mais diversos capítulos, argumentos decisivos sobre a liberdade de pensar, filosofar e ensinar filosofia.

Não é sem razão que o subtítulo do Teológico-político define a obra como um tratado "onde se mostra que a liberdade de filosofar não só é compatível com a preservação da piedade e da paz, como não pode ser abolida sem se abolir a paz da República e a própria piedade". Em diversas passagens do livro, Espinosa menciona o problema do ensino e revela toda a riqueza de sua formação na 
língua hebraica, aplicando-a a uma interpretação rigorosa da religião, da filosofia e da necessária separação entre ambas.

O Tratado político, por sua vez, sintetiza em breves linhas, no final do oitavo capítulo, como seria a educação em uma República livre; o desenvolvimento do assunto, prometido para depois, não chegou a ser feito, em função da morte do autor. Todavia, na Carta 48 da Correspondência de Espinosa (que contém a recusa do filósofo em ensinar filosofia em Heidelberg), está explicitado muito daquilo que certamente seria incluído em sua concepção política de educação.

A própria Correspondência evidencia ainda uma dimensão pedagógica especial. O filósofo, no início de uma mensagem destinada a Blyenbergh (Carta 21), confere aos diálogos que estabelece por escrito com seus discípulos à maneira de possibilidade de uma "mútua erudição" em assuntos filosóficos.

Como é manifesto, muito da obra de Espinosa está profundamente ligado aos problemas da educação. No entanto, até o começo do século $X X$ pouquíssima atenção se dedicou a isso.

Em 1911 foi publicada a primeira tentativa sistemática de confronto entre o pensamento de Espinosa e problemas educacionais. William Rabenort, em Spinoza as Educator (livro que em breve será editado em língua portuguesa), apresenta um Espinosa atento e interessado pelo problema da formação humana; orientado pelas perspectivas pedagógicas de seu tempo, marcadas pelo evolucionismo. Rabenort inaugurou assim a consideração de Espinosa como pensador de questões relativas à pedagogia. 
Mais de vinte anos depois, já em 1933, o filósofo italiano Adolfo Ravà, que provavelmente desconhecia o trabalho de Rabenort, escreveu o artigo "La pedagogia di Spinoza", traduzido e publicado neste dossiê exatamente oitenta anos depois de sua publicação original. No trabalho, Ravà retoma vários estudos da década de 1920 que, mesmo sendo breves, trazem uma série de elementos novos para se cogitar as relações entre o tema da educação e o espinosismo. Desde o tratamento dispensado ao Tratado da emenda do intelecto até a Ética, passando por inúmeras questões relativas à vida de Espinosa e sua habilidade didática na composição do Compêndio de gramática da língua hebraica, o autor italiano abre frentes para novas pesquisas em torno de uma possível educação espinosana.

Deve-se dizer uma "possível" educação espinosana porque ainda permanece viva a discussão sobre a (im)possibilidade e/ou necessidade da educação em uma filosofia como a de Espinosa, conforme o leitor poderá notar na leitura dos artigos de Adolfo Ravà e Tapio Puolimatka. Entretanto, como atesta a realização deste dossiê, é perfeitamente cabível visitar ou revisitar a obra de Espinosa armados dos interesses de um leitor pedagogo e colher profícuos resultados.

Estão reunidos aqui estudos realizados por pesquisadores brasileiros (de diversas regiões do país) e estrangeiros. Todos são, cada um à sua maneira, leitores de Espinosa interessados no problema da educação. Especialistas ou não em filosofia moderna, suas considerações têm como destinatário especial o estudante de 
pedagogia e o estudioso de filosofia da educação. A maior parte dos artigos aqui oferecidos apresenta abordagens interdisciplinares que percorrem a filosofia, a pedagogia, a psicologia e as artes; isso torna a leitura inevitavelmente um pouco difícil, mas, ao mesmo tempo, muito enriquecedora.

A coletânea está organizada em blocos. No primeiro, aparecem quatro artigos teóricos: Luís Machado de Abreu, Juliana Merçon, Cristiano Novaes de Rezende e Alessandra Costa-Pinto junto a Lisete Rodrigues se dedicam a problemas fundamentais da educação de Espinosa em suas dimensões epistemológicas, éticas e políticas. No segundo bloco aparecem dois artigos sobre a teoria dos afetos na prática pedagógica: o primeiro, de Gisele Toassa, aborda a questão na perspectiva do trabalho docente e o segundo, de Lavínia Magiolino, trata a vivência das emoções no processo de formação discente.

O terceiro momento do dossiê compreende outros dois artigos escritos tendo em vista as relações entre Espinosa e a prática pedagógica: o primeiro deles foi produzido pela pesquisadora argentina Andrea Pac, e o segundo foi elaborado por Ana Luiza Smolka e Raquel Minako Kusunoki, ambas empenhadas há tempos na tarefa de pensar Espinosa em suas inquietantes relações com a psicologia de Vigotski.

O último bloco de textos contém três artigos teóricos: um de Fernando Bonadia de Oliveira e outros dois de Tapio Puolimatka e Adolfo Ravà. $\mathrm{O}$ artigo de Puolimatka foi gentilmente traduzido por Victor Fiori Augusto, estudante de Filosofia da USP dedicado ao 
estudo do pensamento espinosano; o trabalho de Ravà foi traduzido por Emanuel Fragoso, Fernando Bonadia de Oliveira, Homero Santiago e Kácia Natália de Barros, pesquisadores de São Paulo e do Ceará.

Esperamos, por fim, que a leitura deste dossiê possa trazer subsídios para se pensar a inserção de Espinosa nos estudos pedagógicos de uma maneira definitiva, permitindo a proliferação de novos estudos sobre o tema. 